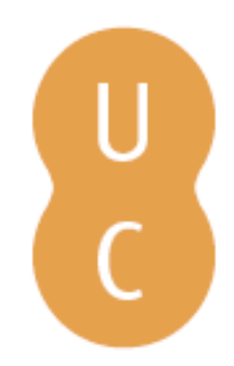

\title{
nommalina
}

\section{Peregrinationes ad loca sancta: o estranho percurso de Melânia-a-Antiga num Mediterrâneo globalizado}

\author{
Autor(es): $\quad$ Furtado, Rodrigo \\ Publicado por: Imprensa da Universidade de Coimbra \\ URL \\ persistente: URI:http://hdl.handle.net/10316.2/45227 \\ DOI: $\quad$ DOI:https://doi.org/10.14195/978-989-26-1626-1_18 \\ Accessed : $\quad$ 26-Apr-2023 16:16:34
}

A navegação consulta e descarregamento dos títulos inseridos nas Bibliotecas Digitais UC Digitalis, UC Pombalina e UC Impactum, pressupõem a aceitação plena e sem reservas dos Termos e Condições de Uso destas Bibliotecas Digitais, disponíveis em https://digitalis.uc.pt/pt-pt/termos.

Conforme exposto nos referidos Termos e Condições de Uso, o descarregamento de títulos de acesso restrito requer uma licença válida de autorização devendo o utilizador aceder ao(s) documento(s) a partir de um endereço de IP da instituição detentora da supramencionada licença.

Ao utilizador é apenas permitido o descarregamento para uso pessoal, pelo que o emprego do(s) título(s) descarregado(s) para outro fim, designadamente comercial, carece de autorização do respetivo autor ou editor da obra.

Na medida em que todas as obras da UC Digitalis se encontram protegidas pelo Código do Direito de Autor e Direitos Conexos e demais legislação aplicável, toda a cópia, parcial ou total, deste documento, nos casos em que é legalmente admitida, deverá conter ou fazer-se acompanhar por este aviso.

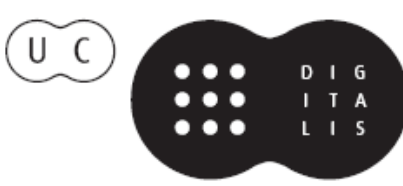




\section{Arqueologias de Império}

\section{Delfim Leão, José Augusto Ramos, Nuno Simões Rodrigues (coords.)}

IMPRENSA DA UNIVERSIDADE DE COIMBRA 


\title{
PEREgRINATIONES AD LOCA SANCTA: O ESTRANHO PERCURSO DE MelÂNiA-A-Antiga NUM Mediterrâneo globalizado (Peregrinationes ad loca sancta: the strange route of Melania-the-Elder in a globalised Mediterranean)
}

\author{
RODRIGO FURTADO \\ (rodrigofurtado@campus.ul.pt; ORCID: 0000-0002-6720-5030) \\ Universidade de Lisboa, Faculdade de Letras, Centro de Estudos Clássicos
}

Resumo - Este texto resulta das incongruências, omissões, lapsos e reconstruções das fontes sobre Melânia-a-Antiga. Procurarei aduzir elementos que esclarecem: (i) que Melânia partiu para o Oriente ca. 374, mais de dez anos depois de ter ficado viúva; (ii) no contexto das perseguições de Valentiniano I; (iii) e que primeiro rumou ao Egito, antes de se estabelecer na Palestina. Procurarei ainda (iv) situar o regresso de Melânia a Roma no contexto do conflito generalizado entre os mosteiros de Jerusalém e os monges do Egito, por um lado, e Jerónimo, o seu mosteiro de Belém e Teófilo de Alexandria, por outro.

Palavras-chave: Peregrinação; Antiguidade tardia; Melânia-a-Antiga; Cristianismo - sécs. IV-V.

Abstract - This text is an analysis of the incongruities, omissions, lapses and reconstructions of the sources about Melany-the-Ancient. I will defend (i) that Melania left Rome for the East ca. 374, more than ten years after she became a widow; (ii) in the context of the persecutions of Valentinian I; (iii) and that she went first to Egypt, before settling in Palestine. I will also (iv) analyse Melania's return to Rome in the context of the general conflict between the monasteries of Jerusalem and the monks of Egypt, on the one hand, and Jerome, his monastery in Bethlehem and Theophilus of Alexandria, on the other.

Keywords: Pilgrimage; Late Antiquity; Melania-the-Elder; Christianity - IVth-Vth century.

Por volta do ano 370 d.C., o Mediterrâneo era um mar romano há cerca de quatrocentos e trinta anos, desde pelo menos a eliminação pompeiana dos piratas e as subsequentes conquistas do Magno em terras orientais, e sobretudo com o domínio romano da estratégica ilha de Chipre pelo republicano Catão de Útica. Naturalmente, a cosmópolis à escala do Mediterrâneo Oriental era bem anterior: no ano 370, durava há pelo menos setecentos anos, desde que Alexandre derrubara o dominó persa. Quatrocentos e trinta ou setecentos anos é, grosso modo, o tempo que nos separa a nós, em Portugal, do início do período filipino, ou, mais ainda, do rei D. Dinis. Era muito tempo. Por isso, creio que, tal como para nós, seria difícil para os homens da segunda metade do século IV 
d.C. conceber a possibilidade de um mundo diferente daquele em que viviam. E, no entanto, ele estava a mudar, e de forma acelerada: as reformas de Diocleciano e de Constantino transformaram irremediavelmente o Império, e não apenas em termos religiosos como estamos habituados a considerar.

Neste mundo globalizado, há um fenómeno que, não sendo obviamente generalizado, ganha agora uma dimensão nova: o das peregrinações ${ }^{1}$. Em latim, há pelo menos duas palavras que designam o fenómeno - peregrinatio, claro; e iter. Ambos os lemas têm também outros significados, e não deixa de ser curioso que Egéria, por exemplo, prefira referir-se ao seu iter e nunca à sua peregrinatio. De qualquer modo, e de forma simples e clara, 'peregrinação' surge como todo o tipo de viagem com objetivos religiosos/espirituais's ${ }^{2}$ Neste sentido, a peregrinação implica normalmente uma deslocação longa e difícil (e frequentemente a própria viagem, num mundo em que ainda não havia 'caminhos' de peregrinação, era considerada mais densa em termos espirituais do que o destino em $\mathrm{si}^{3}$ ) a um determinado local tido como sagrado e/ou uma visita a um determinado "holy

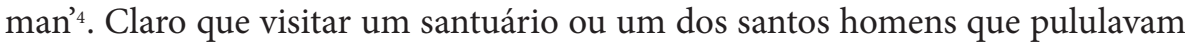
sobretudo no Oriente do Império não era um fenómeno apenas cristão: Delfos, Dídima, Olímpia, ou os santuários de Asclépio em Epidauro ou em Pérgamo, neste último caso com um notável equipamento de hotel \& $\mathrm{spa}^{5}$, eram destinos frequentes; e deixo também de lado o caso dos pregadores itinerantes, como Proclo, biografado por Marino de Nápoles, ou os vários 'filósofos' e 'sofistas' cujas vidas interessaram a Eunápio.

Pelo menos nos primeiros tempos, o Cristianismo conhecera vários destes pregadores itinerantes, a começar pelo próprio Jesus de Nazaré ou por Paulo de Tarso. Apesar de tudo, será difícil encontrar casos evidentes de 'peregrinação' entre cristãos, pelo menos até ao século IV: não creio que os dois exemplos que por vezes são dados, o de Alexandre de Jerusalém (que terá fugido no século III da perseguição na Capadócia ${ }^{6}$ ) e o de Militão de Sardes (que terá rumado à Palestina para procurar cópias fidedignas das Escrituras ${ }^{7}$ ), encaixem bem no conceito de peregrino.

Nem mesmo com Helena, a mãe do imperador Constantino, as motivações religiosas foram razão primeira para a viagem à Palestina em 3268: mesmo se

${ }^{1}$ Cf. Wilkinson 1977; V. Turner et E. Turner 1978; Hunt 1982; Maraval 1985; Bitton-Askelony 1999; Webb 1999; Marcos 2004; Dietz 2005.

${ }^{2}$ Sigo a definição de Dietz 2005, 30.

${ }^{3}$ Dietz 2005, 30: «reaching a particular destination was often less important than the journey itself».

${ }^{4}$ O título clássico é o de Brown 1971. Atualizações em Cameron 1999; Dahlman 2007; Rubenson 2008

${ }^{5}$ Referência de Dietz 2005, 32 .

${ }^{6}$ Cf. Eus. hist. eccl. 9.2.

${ }^{7}$ Cf. Eus. hist. eccl. 4.26.

${ }^{8}$ Drijvers 1992; Pohlsander 1996. 
Eusébio de Cesareia garante que a Augusta queria rezar nos locais outrora frequentados por Cristo, é também ele que nos diz que Helena tinha sido enviada para inspecionar as províncias orientais com as suas comunidades e povos. Outras mulheres (quase sempre mulheres, de facto) se lhe seguiram, embora muitas vezes meros nomes: Martana parece ter liderado uma comunidade feminina na Síria ${ }^{10}$; ou, talvez melhor, a extravagante Peménia parece ter patrocinado a Igreja da Ascensão em Jerusalém ${ }^{11}$. Por fim, ainda no século IV, mencione-se Egéria ${ }^{12}$.

Nenhuma destas mulheres, no entanto, me ocupará aqui. Este meu texto surge do cruzamento de duas leituras: por um lado, a tese de Maribel Dietz, Wandering monks, virgins, and pilgrims. Ascetic travel in the Mediterranean world, que procura mostrar a diversidade de motivações que terá estado por trás do fenómeno das peregrinações até à época de Carlos Magno; por outro, o conjunto de leituras sobre Melânia-a-Antiga através das epístolas de Jerónimo e de Paulino de Nola e sobretudo da Historia Lausiaca de Paládio. Quando comecei a estudar Melânia e resolvi consultar o livro de Dietz, percebi que, muito provavelmente, haveria mais a dizer do que aquilo que a autora norte-americana deixa entender sobre esta personagem, de resto com pequenas imprecisões ${ }^{13}$. A leitura posterior de um artigo de Franca Ela Consolino e da Melaniana de Nicole Moine permitiu perceber que a vida de Melânia continha algumas inconsistências em que importava ainda atentar ${ }^{14}$. Muito recentemente, em 2016, o livro de C. M. Chin e C. T. Schroeder acaba por retomar e desenvolver algumas das questões que, em 2013, eu próprio tinha tratado, no contexto do congresso que deu origem a este estudo ${ }^{15}$. Também posterior, o excelente artigo de K. W. Wilkinson é o que mais se aproxima do tema que aqui proponho estudar ${ }^{16}$. Apesar de tudo, julgo que sobretudo quanto à data da partida da Roma e aos motivos dessa partida, este meu contributo acrescenta elementos a este último texto.

Melânia-a-Antiga pertencia à gens Antonia. Descendia de António Marcelino, praeses Lugdunensis na época da tetrarquia, procônsul da África e oficial do imperador Constante ${ }^{17}$. António tinha pertencido ao colégio de prefeitos do pretório, foi procônsul da Itália, Ilíria e África entre 340-342 e cônsul em 341. Melânia casou com um membro da ainda mais prestigiada gens Valeria ${ }^{18}$,

\footnotetext{
${ }^{9}$ Vita Const. 3.42

${ }^{10}$ Egéria 23.3

${ }^{11}$ Pall. hist. laus. 35.14-15 Butler; João Rufo, Vita Petri Iberi 30.13-18; cf. Devos 1969; Devos

${ }^{12}$ Veja-se Mariano et Nascimento 1998, com bibliografia.

${ }^{13}$ Cf. Dietz 2005, 122-23.

${ }^{14}$ Moine 1980; Consolino 2006, especialmente as pp. 75-84.

${ }^{15}$ Chin et Schroeder 2016.

${ }^{16}$ Wilkinson 2012.

${ }^{17}$ PLRE 1, 548-549, «Marcellinus 16»

${ }^{18}$ Paul. Nol. ep. 29.8
} 1973. 
provavelmente com o prefeito da Cidade em 361, Valério Máximo ${ }^{19}$. Ora, este Valério Máximo (se tiver sido mesmo ele o marido de Melânia) não era um qualquer: Gala, a primeira mulher de Júlio Constâncio, meio-irmão de Constantino I, era sua tia materna ${ }^{20}$. A imperatriz Justina, mulher do imperador Valentiniano I e depois regente do impúbere Valentiniano II, deve ter sido também sua prima ${ }^{21}$. O pai de Valério Máximo tinha sido vigário do Oriente em 325, prefeito do pretório do Oriente entre 327-8, da Gália com Constâncio César em 332-3, e no Danúbio em 337 com Dalmácio César ${ }^{22}$.

Não se sabe desde quando Melânia era cristã. Após várias gestações, algumas delas frustradas ${ }^{23}$, Melânia perdeu o marido e dois dos seus filhos no curto prazo de um ano. E é aqui que começam os nossos problemas.

No ano 384, São Jerónimo, na carta que escreverá à sua amiga Paula quando da morte da filha desta, Blesila, recorda Melânia como exemplo de virtudes, ela que enfrentara com coragem a perda de dois filhos e do marido. Traduzo:

Não derramou qualquer lágrima; permaneceu imperturbável e, arrojando-se aos pés de Cristo, sorriu, como se o tivesse a ele próprio nos braços: «Servir-teei agora mais devotadamente, Senhor, porque me livraste de tão grande peso» [i.e do marido e dos filhos]. [...] Com o mesmo pensamento com que despreza os que tinham morrido, assim o prova depois em relação ao seu único filho, quando, deixando-lhe tudo quanto tinha e tendo começado já o Inverno, navegou para Jerusalém (Hier. ep. 39.5).

Paládio conta uma história semelhante:

Ficando viúva aos 22 anos, foi digna do amor divino, e, sem dizer nada a ninguém (pois tê-la-iam impedido, naqueles tempos em que Valente governava o império), designou um tutor para o filho, tomou consigo todos os seus bens móveis e pô-los num barco, com alguns servos e escravas; depois, zarpou a toda a pressa para Alexandria (Pall. hist. laus. 46.1).

O texto de Paulino de Nola é bastante mais longo, mas confirma grosso modo as informações anteriores. Portanto, e conjugando os textos destes três autores, Melânia abandonou o filho, Valério Publícola, ainda não com catorze $\operatorname{anos}^{24} \mathrm{e}$ atravessou o Mediterrâneo em pleno Inverno. Contudo, esta partida não

\footnotetext{
${ }^{19}$ Amm. 21.12.24; cf. PLRE 1, 583 «Maximus 17».

${ }^{20}$ PLRE 1, 382 «Galla 1»

${ }^{21}$ Chausson 2007, 97-187.

${ }^{22}$ PLRE 1, 590-591 "Maximus 49"

${ }^{23}$ Paul. Nol. ep. 29.8.

${ }^{24}$ Paul. Nol. ep. 29.8; Hier. chron. a. 374 Helm; Pall. hist. laus. 46.1 Butler; cf. Moine, 1980,
} 41-43. 
está isenta de problemas: refiro aqui apenas dois - quando partiu afinal Melânia? E, aparentemente mais evidente, porque partiu Melânia?

Começo pela primeira pergunta: de acordo com os três textos que referi, de Jerónimo, Paládio e Paulino de Nola, não terá decorrido muito tempo entre a morte dos seus entes queridos e a partida para o Oriente; todos querem fazer crer que a decisão de Melânia de abandonar tudo e cruzar o Mediterrâneo foi quase imediata... e, no entanto, atentemos em três pormenores: Paládio diz que Melânia deixou Itália no principado de Valente, isto é, entre 364 e 378. Este intervalo circunscreve o acontecimento, mas é ainda demasiado largo. Um pouco mais à frente na sua Historia Lausiaca, o mesmo Paládio assegura que, quando do regresso de Melânia a Itália no ano 400, já há 37 anos que a matrona levava uma existência dedicada à caridade e à ascese ${ }^{25}$ : fazendo as contas, 400-37, chegamos ao ano 363. O mesmo Paládio ${ }^{26}$ afirma que em 400 Melânia teria sessenta anos: teria, pois, nascido por volta do ano 340. Sendo assim, continuando a acreditar em Paládio, Melânia teria ficado viúva em 362, com os vinte e dois anos que ele próprio refere. Todos estes dados são compatíveis com os textos: se o marido de Melânia tiver morrido em 362, ela pode ter abraçado uma vida de caridade e ascese já viúva em 363 e pode ter partido para o Oriente no ano seguinte, já depois de 28 de Março de 364, quando Valente assumiu o principado: para todos os efeitos, tudo teria ocorrido num tempo curto. Contudo, Paládio acrescenta uma outra informação que vem perturbar este edifício cronológico. Ele também diz que a matrona permaneceu em Jerusalém durante vinte e sete anos: ora, $400-27=373$, o que significa cerca de dez anos depois do período que estávamos a considerar. De resto, o mesmo Paládio diz ainda que Melânia estaria no Egito quando da perseguição movida por Valente contra os monges do Egito, fiéis a Niceia: ora, esta perseguição ocorreu apenas após a morte do centenário Atanásio de Alexandria, em 2 de Maio de $373^{27}$.

Recapitulemos: Paládio diz que Melânia tinha sessenta anos, quando regressou a Itália; que tinha 22 anos quando ficou viúva; que, logo após a morte do marido, decide deixar o filho em Roma e parte para Alexandria, durante o principado de Valente; e que, no ano 400, se entregava à vida ascética há já trinta e sete anos. Contudo, diz também que a sua presença em Jerusalém durou só 27 anos, e que, algures depois de 2 de Maio de 373, estaria no Egito e não na Palestina. Ou Paládio se enganou nas contas (é possível); ou algum copista se enganou a copiar as datas (o que é ainda mais provável). Descarto desde já a hipótese de Melânia ter ficado no Egito 10 anos, entre 364-373, entre deixar a Itália e rumar

\footnotetext{
${ }^{25}$ Pall. hist. laus. 54 Butler.

${ }^{26}$ Pall. hist. laus. 54.3 Butler.

${ }^{27}$ Pall. hist. laus. 46.3 Butler.
} 
a Jerusalém: ela não é compatível com o texto do próprio Paládio. Segundo este mesmo autor, Melânia teria ficado no Egito apenas ñj

Jerónimo e Paulino de Nola ajudam a esclarecer o imbróglio. Paulino, que era familiar de Melânia e em cuja casa de Nola ela foi acolhida quando chegou a Itália no ano 400, diz que a matrona teria permanecido em Jerusalém durante cinco lustros, isto é, vinte e cinco anos ${ }^{28}$ : fazendo as contas, ficamos com a data de 375 , ano que cai dentro ainda do principado de Valente, mas é ainda irreconciliável com o tal curto período de tempo decorrido entre a viuvez de Melânia e o abandono de Roma. Já esta a informação sobre os vinte e cinco anos é compatível, grosso modo, com os vinte e sete de estadia em Jerusalém, referidos por Paládio: algures entre 373 e 375, Melânia chegou a Jerusalém. Jerónimo é o mais explícito dos três autores: na primeira edição do seu Chronicon, diz que a partida de Melânia de Roma terá ocorrido no décimo ano do principado de Valente, já em $374^{29}$. Paulino e Jerónimo estão, pois, mais ano menos ano, de acordo com a informação de Paládio que dá Melânia em Jerusalém durante vinte e sete anos; mas, de modo algum, com a ideia de que, tendo ficado viúva em 362, Melânia teria partido de imediato para o Oriente. Creio que é esta ideia que deve ser abandonada. Tendo ficado viúva provavelmente em 362, Melânia abandonou Roma de facto, mas apenas cerca de onze-doze anos depois, em 373-374; é evidente que Jerónimo, Paulino e Paládio querem dar a impressão de que tudo aconteceu de forma muito rápida na 'vocação' cristã de Melânia; não deve ter sido assim: durante mais de dez anos, Melânia deve ter vivido a sua 'vida obscura' em Roma com o filho e outros familiares, que, de resto, se terão oposto com ferocidade ao seu novo modo de vida, segundo o que nos conta Paulino de Nola.

Por que razão partiu então Melânia para o Oriente, deixando o próprio filho? Paulino de Nola diz que «abandonando o mundo e o século, escolheu como dom espiritual a cidade de Jerusalém, onde peregrinaria para fora do seu corpo, exilada em relação aos seus co-cidadãos, tornando-se cidadã entre os santos». ${ }^{30}$ Cabe reconhecer o carácter pioneiro de Melânia no ato de se retirar de um mundo de honras, para se dedicar através da ascese à vida espiritual. E, contudo, há pormenores que colocam problemas a esta interpretação: antes de mais, a referência de Paládio ao facto de Melânia ter partido sem dizer nada a ninguém. Depois, a ideia de poder vir a ser impedida de partir, especialmente na época em que Valente governava o império. Mas, o que tem Valente a ver com isso? Ele era imperador na metade oriental do Império; Valentiniano I era-o no Ocidente, Roma inclusive. De qualquer modo, por que razão haveria o imperador, qualquer que ele fosse, de ameaçar eventualmente a saída de Melânia?

\footnotetext{
${ }^{28}$ Ep. 29.6.

${ }^{29}$ Hier. chron. a. 374 Helm

${ }^{30}$ Ep. 29.10
} 
A família de Melânia opôs-se ferozmente à sua vida ascética ${ }^{31}$. Estaria Melânia a fugir da família, tentando evitar que a impedissem de partir? É possível, mas isso não explica a referência ao imperador.

Um olhar pela Roma do ano 373 pode sugerir uma outra razão, relacionada com um imperador (embora mais Valentiniano I do que Valente). De acordo com o historiador Amiano Marcelino, que nunca fala de Melânia, os anos entre 369-375 em Roma foram caracterizados pela imposição da autoridade imperial na Urbe, muitas vezes contra o Senado. Deve ter sido um processo importante e a elite senatorial entendeu-o como um ataque a si própria ${ }^{32}$. É neste mesmo contexto que, talvez no início de 374, também Dâmaso, o bispo de Roma, é acusado de ser responsável pelo massacre de seis anos antes na Basílica Júlia, em pleno forum romanum, e também pelo assalto na mesma altura à basílica de Latrão, que causara a morte de cento e setenta pessoas ${ }^{33}$. Não conheço relações directa entre Melânia e Dâmaso, mas um dos éditos de Valentiniano I, de 30 de Julho de 370, proibia de facto que os clérigos procurassem convencer as matronas romanas a deixar-lhes os seus bens ${ }^{34}$.

Ora, precisamente essa era uma acusação lançada pelas famílias de mulheres que, como Melânia, pretendiam abandonar tudo e dedicar-se a uma vida de caridade e ascese: estariam a ser aliciadas pelo bispo de Roma ou pelos seus amigos? E sabemos como a família de Melânia se opôs aos seus desígnios de doar tudo aos pobres e à Igreja ${ }^{35}$. Seria Melânia próxima do bispo de Roma? Não sei.

Mas, a relação difícil de estabelecer entre Melânia e Dâmaso não é a única que talvez, como hipótese, a relacione com o contexto dos processos judiciários de 369-375 em Roma. Um dos senadores condenados foi um tal Avieno, já depois de 372, mais ou menos pela altura em que Melânia abandonou furtivamente Roma. Não se conhece a sua árvore genealógica; contudo, Macróbio ${ }^{36} \mathrm{e}$ Sidónio Apolinário $^{37}$, a propósito de outros nobres com o mesmo nomen, dizem que eles eram parentes dos tardios Valérios Messala Corvino. Ora, um dos membros desta família era precisamente o marido de Melânia; e não pode ser por acaso que o filho de ambos se veio a chamar Valério Publícola, precisamente o nome do primeiro cônsul da República de quem o Valério Messala, amigo de Rutílio Namaciano, reclamava descender ${ }^{38}$. Há, pois, boas hipóteses de que Avieno seja primo do marido de Melânia. Não é muito.

\footnotetext{
${ }^{31}$ Paul. Nol. ep. 29.10.

${ }^{32}$ Embora a precisar de melhor investigação, vejam-se Alföldy 1952; Hamblenne 1980; Matthews 1989; Vincenti 1991.

${ }^{33}$ Pietri 1976, 409. Para o contexto do conflito, veja-se a síntese de Pietri 1976, 407-23.

${ }^{34}$ Pietri 1976, 419.

${ }^{35}$ Paul. Nol. ep. 29.10.

${ }^{36}$ Macr. Sat. 1.6.26.

${ }^{37}$ Ep. 1.9.4.

${ }^{38}$ De reditu suo 1. 267-276.
} 
Contudo, é tentador notar que tudo acontece na mesma altura em que Melânia parte às escondidas para o Oriente ${ }^{39}$. Que tivesse aproveitado alguma fragilidade da sua família ou que ela própria se sentisse insegura em Roma são boas razões para uma fuga em pleno Inverno.

Há ainda um terceiro problema a propósito desta partida de Melânia para o Oriente. Paulino de Nola e Jerónimo dizem explicitamente que, ao sair de Roma, Melânia foi para Jerusalém. No entanto, Paládio fá-la rumar antes ao Egito, como já referi. Aqui, Paládio diz que ela visitou os monges ascetas da Nítria, de onde se destacam Pambão, os 'Irmãos Makpoi', Arsísio, Serapião o Grande, Pafnúcio de Escetes e Isidoro de Alexandria ${ }^{40}$. Ora, quando saiu (ou fugiu?) de Roma, Melânia ou foi para um lado ou para o outro; não foi para os dois lados ao mesmo tempo.

Há pelo menos três fatores que levam a que, neste caso, confiemos mais na versão de Paládio: em primeiro lugar, fontes independentes asseguram que Melânia manteve com os monges da Nítria relações privilegiadas ao longo de toda a sua vida - o próprio Paládio era um destes monges do deserto que se convertera ao ascetismo, segundo ele próprio conta, depois de se ter encontrado com Melânia ${ }^{41}$. Os 'Altos Irmãos', Isidoro, Evágrio e Paládio representam os mais influentes padres do deserto no Egito de finais do século IV e inícios do século V. No Outono de 394, sete monges dos mosteiros de Melânia e de Rufino de Aquileia estarão no Egito, com o asceta João de Licópolis. Melânia era próxima, pois, destes monges do Egito, e faz sentido que aí se possa ter encontrado com eles ${ }^{42}$.

Além disso, de acordo com Paládio, quando Valente persegue estes monges do Egito depois da morte de Atanásio e estes fogem para a Palestina, Melânia foi com eles para Diocesareia ${ }^{43}$ : a formal verbal usada é $\sigma v v \varepsilon \lambda \theta 0$ ov $\sigma \alpha$ (o particípio

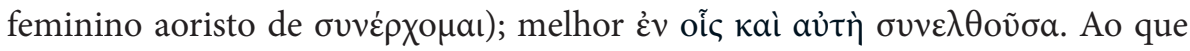
parece, pois, segundo Paládio, Melânia estava no Egito quando Valente lançou mais uma das suas perseguições contra os monges ascetas partidários de Niceia. Só depois disso se teria estabelecido em Jerusalém.

Último factor: Dietz mostrou que uma das características das peregrinações no século IV, pelo menos tão importante quanto a visita a locais santos, terá sido a visita aos homens santos: a contemporânea de Melânia, Egéria, que também passou pelo Egito antes de se encaminhar para a Palestina, é disso exemplo; pela mesma altura, também Jerónimo, Paula e Eustóquio irão primeiro ao Egito, antes de se estabelecerem em Belém; esta mesma Paula continuará as suas visitas

\footnotetext{
${ }^{39}$ Pietri 1976, 419.

${ }^{40}$ Pall. hist. laus. 5.2-3, 9, 10.2-4, 46.2 Butler, hist. laus. 10D Amélineau.

${ }^{41}$ Pall. hist. laus. 44 Butler.

${ }^{42}$ Hist. monach. prol. 2, 1.19, 1.64, 26.10 Festugière.

${ }^{43} 46.3$ Butler.
} 
aos homens santos, desta feita no Chipre e de novo no Egito ${ }^{44}$. Sendo assim, que Melânia tenha começado por passar meio ano no Egito, como refere Paládio, não é algo excecional, mas uma característica do próprio ato de peregrinar na Antiguidade Tardia.

Ora, neste mundo globalizado que é o Mediterrâneo romano, 'santa Melânia' deixou Roma para se dirigir para Oriente. Não se tratou de uma decisão tomada logo após a morte do marido, como os seus «biógrafos» querem fazer crer - apenas 11-12 anos depois de enviuvar, ela saiu de Roma. Provavelmente, esperou que o filho se pudesse candidatar a praetor urbanus e iniciar, pois, o percurso das honras. A saída de Roma foi, no entanto, furtiva, sem dizer nada a ninguém, durante o Inverno. $\mathrm{O}$ ambiente de perseguição que se vivia na Urbe contra alguns dos membros do senado, até contra possivelmente um familiar do marido, pode ter apressado a partida de Melânia. Não rumou à Palestina, como Jerónimo e Paulino dizem - por certo, foi primeiro ao Egito visitar os santos Padres do deserto, como refere um deles, Paládio. Parecendo que não, este dado pode levar a reconsiderar a sua viagem - e se Melânia não tivesse intenção, desde o início, de se vir a estabelecer na Palestina, mas procurasse de facto fazer uma autêntica peregrinação, como uma viagem longa, mas de ida e volta, à semelhança de Egéria? De resto, se Paládio tiver razão, terá sido um acontecimento absolutamente fortuito, a perseguição de Valente aos monges da Nítria, a obrigar Melânia a estabelecer-se na Palestina ${ }^{45}$, onde a matrona milionária acabará por fundar um mosteiro em Jerusalém, em pleno Monte das Oliveiras, que chegará a acolher cinquenta virgens.

Como já vimos, Melânia só voltará a Itália, cruzando de volta o Mediterrâneo romano no ano 400. É Paládio o único que explica por que razão o terá feito:

Depois de muitos anos, quando ouviu falar da neta, que ela tinha casado e desejava renunciar ao século, talvez para que ela não fosse arrastada para alguma má doutrina, heresia ou má vida, embarcou num navio aos sessenta anos e, a partir de Cesareia, chegou a Roma vinte dias depois ${ }^{46}$.

A que se refere Paládio? Sem o fazer explicitamente, julgo que ele se refere à famosa controvérsia origenista que opôs Jerónimo a Rufino de Aquileia e aos padres do deserto egípcios, e na qual Melânia se verá envolvida já nos anos 90 do século IV ${ }^{47}$.

Esta era uma polémica em torno da doutrina cristã e do pensamento de Orígenes de Alexandria, o maior teólogo cristão do século III: a discórdia entre

\footnotetext{
${ }^{44}$ Dietz 2005, 121, 123, 126-28, 133, 137.

${ }^{45}$ Pall. hist. laus. 46.3-4 Butler; Paul. Nol. ep. 29.11.

${ }^{46}$ Pall. hist. laus. 54 Butler.

${ }^{47}$ Clark 1992; Furtado 2013.
} 
Jerónimo e Rufino, este último o principal amigo de Melânia no Oriente, radicava em torno de assuntos como a pré-existência ou não das almas humanas em relação ao corpo; a inferiorização do corpo e de toda a criação material; ou a ausência de ressurreição da carne. Ora, regressado a 397, em Roma Rufino de Aquileia traduzira a Apologia Origenis da autoria de Panfílio e o Peri Archōn de Orígenes. Foi o suficiente para que os amigos romanos de Jerónimo procurassem a condenação do amigo de Melânia por difundir doutrinas origenistas. Estas traduções perderam-se, mas não produziram em Roma a condenação imediata de Rufino, talvez porque o papa Siríaco não devia manter boas relações com Jerónimo desde que sucedera a Dâmaso em 384. Assim eram as relações entre os santos naqueles tempos.

Siríaco morreu por sua vez em 399 e foi sucedido por Anastácio. O novo bispo de Roma parece dar mais ouvidos aos anti-origenistas e procura concitar o apoio do bispo de Milão contra os que defendiam estas doutrinas. No ano 400, Rufino estava, pois, em perigo, assim como as doutrinas origenistas defendidas sobretudo pelos Padres do deserto egípcios, os também amigos de Melânia.

Em todo este conflito, Melânia estará do lado de Rufino, o que lhe valerá a inimizade posterior de Jerónimo, que falará dela como aquela 'cujo nome, que designa escuridão, é bem testemunha das trevas da sua perfídia' ${ }^{38}$. A etimologia do nome de Melânia (cf. $\mu \varepsilon \lambda \alpha$ vía=nigredo) apontava, de facto, para a escuridão. O desentendimento vai a tal ponto que Jerónimo apaga Melânia da nova edição do seu Chronicon. É neste contexto que a matrona regressa a Itália: é provável que a 'má doutrina, a heresia e a má vida' que ameaçariam a neta, também chamada Melânia, possam ser entendidas, pois, no contexto deste combate doutrinal entre Rufino e os partidários de Jerónimo em Itália.

E contudo... sem rejeitar essa possibilidade, pergunto-me se Melânia terá abandonado Jerusalém de tão livre vontade, para proteger os seus contra as perigosas doutrinas de Jerónimo.

De facto, não foi apenas em Itália que recrudesceu em 399-400 a luta contra os partidários das doutrinas de Orígenes, por iniciativa de Anastácio de Roma. Também a Oriente, precisamente nestes anos, o poderoso bispo Teófilo de Alexandria desencadeava uma dura perseguição contra os monges do Egito (que tinham entretanto regressado às suas celas, talvez após a morte de Valente). Foram pouco teológicos os motivos que levaram à perseguição de Teófilo, ele que antes defendera e protegera os monges do deserto: efetivamente, os historiadores Sócrates e Sozómeno falam da descoberta de irregularidades financeiras e de corrupção na igreja de Alexandria ${ }^{49}$ e na recusa do monge Isidoro (o amigo de Melânia), em entregar o dinheiro das esmolas destinadas aos pobres para o

\footnotetext{
${ }^{48}$ Hier. ep. 133.3.

${ }^{49}$ Socr. hist eccl. 6.7; Soz. hist. eccl. 8.12.
} 
programa de construção de igrejas defendido pelo bispo ${ }^{50}$. Certo é que Teófilo, usando o pretexto do pensamento origenista que muitos destes monges partilhavam, excomungou-os e queimou-lhes as celas; muitos deles fugiram primeiro para Jerusalém (talvez para o Monte das Oliveiras, onde Melânia os pode ter acolhido), e depois para Escitópolis, na Decápolis ${ }^{51}$. Contudo, não ficam aí... não pode ser por mero acaso que nenhum dos monges egípcios que conhecemos tenha permanecido na Palestina depois de 400: encontramo-los logo a seguir em Constantinopla ${ }^{52}$. Mas, por que razão não ficaram os monges na Palestina? Creio saber porquê: Sozómeno diz que Teófilo procurou o favor da corte de Constantinopla para a sua causa contra os monges do deserto, obrigando-os a rumarem ao Bósforo para se defenderem das acusações. Além disso chegou até nós uma carta de Teófilo de Alexandria aos bispos da Palestina e do Chipre (= Hier. ep. 92). Aqui, ele justifica a sua perseguição contra os monges de Nítria e exorta os restantes bispos a imitá-lo (= Hier. ep. 92). Ou seja: Teófilo exorta a que a perseguição seja prosseguida fora do Egito. Se os monges se refugiam em Constantinopla, junto de João Crisóstomo, é verosímil que também não se sentissem seguros na demasiado próxima Palestina, onde se encontrava Melânia. Ora, é precisamente nesta mesma altura, quando Teófilo movia mundos e fundos contra os origenistas, que Melânia parte para Roma: como referi, é mais do que provável que Teófilo tenha estendido a sua perseguição até Jerusalém, tornando pelo menos instável a presença dos monges egípcios e da sua amiga na região - que tenham todos saído da Palestina no mesmo ano é sinal suficiente para aventar a possibilidade.

Resulta este texto, no fundo, das incongruências, omissões, lapsos e reconstruções das fontes sobre Melânia - apesar de normalmente se dizer que uma fonte é tanto mais fidedigna quanto mais próxima estiver dos acontecimentos que narra. $\mathrm{O}$ caso de Melânia é ainda mais excecional, porque os três autores que sobre ela mais falam são todos seus contemporâneos e, melhor ainda, todos eles conheceram Melânia, conversaram com ela, foram próximos dela: Paulino era seu familiar, Paládio converteu-se ao ascetismo graças aos seus ensinamentos e Jerónimo depois de a admirar tornou-se um dos seus inimigos. E, contudo, talvez porque foram tudo isso, deixam-nos uma imagem de Melânia multiforme como santa e como herege. Nesse sentido, o ato de peregrinar no Mediterrâneo Romano-Cristão, se inclui o sentido mais comum da visita a lugares santos, enquadra-se, na verdade, numa semântica poliédrica - Melânia mostra-o. Nem saiu de Roma imediatamente após a viuvez, imbuída por uma qualquer ânsia

\footnotetext{
${ }^{50}$ Socr. hist eccl. 6.9; Soz. hist. eccl. 8.11-15.

${ }^{51}$ Clark 1992, 44-48.

${ }^{52}$ Cf. Leroux 1972, 335-41 e Durand 1976, 191-206.
} 
o estranho percurso de Melânia-a-Antiga num Mediterrâneo globalizado

asceta, nem talvez quando o fez tenha sido a atração pelos Lugares Santos o seu primeiro motivo. Depois de permanecer no Egito, ruma à Palestina não por vontade própria, mas provavelmente expulsa com os monges da Nítria. Um quarto de século mais tarde, se volta a cruzar o Mediterrâneo, já anciã, admito que o tenha feito mais em fuga do que pelo desejo (que não nego também ter existido) de rever ou de proteger os seus familiares e amigos. Peregrinar, peregrinou; contudo, nem sempre as razões espirituais devem ter funcionado como única motivação. 


\section{BibliografiA}

Alföldy, A. 1952. A Conflict of Ideas in the Late Roman Empire: The Clash between the Senate and Valentinian I, trad. Harold Mattingly. Oxford / New York: Oxford University Press.

Bitton-Ashkelony, B. 1999. "The Attitudes of Church Fathers toward pilgrimage to Jerusalem in the fourth and fifth centuries." In Jerusalem. Its sanctity and centrality to Judaism, Christianity, and Islam, ed. L. L. Levine, 188201. New York: Continuum.

Brown, P. 1971. "The Rise and Function of the Holy Man in Late Antiquity." Journal of Roman Studies 61:80-101.

Cameron, Av. 1999. “On Defining the Holy Man», in J. Howard-Johnston - P. A. Hayward." In The Cult of Saints in Late Antiquity and the Early Middle Ages. Essays on the Contribution of Peter Brown, ed. J. Howard-Johnston e Paul Antony Hayward, 27-43. Oxford: Oxford University Press.

Chausson, F. 2007. Stemmata aurea. Constantin, Justine, Théodose: revendications généalogiques et idéologie impériale au Ive siècle ap. J.-C. Roma: «L’Erma » di Bretschneider.

Chin, C. M. e C. T. Schroeder, eds. 2016. Melania: Early Christianity through the life of one family. California: University of California Press.

Clark, E. A. 1992. The Origenist controversy. The cultural construction of an early Christian debate. Princeton: New Jersey.

Consolino, F. E. 2006. "Tradizionalismo e trasgressione nell'élite senatoria romana: ritratti di signore fra la fine del IV e l'inizio del v secolo." In Le trasformazioni delle élites in età tardoantica. Atti del convegno internazionale. Perugia, 15-16 marzo 2004, ed. R. L. Testa, 65-139. Roma: «L'Erma » di Bretschneider.

Dahlman, B. 2007. “The Theme of Secret Holiness.” In Saint Daniel of Sketis: a Group of hagiographic texts edited with introduction, translation, and commentary, 70-89. Uppsala: University of Uppsala.

Devos, P. 1973. “Saint Jerôme contre Poemenia?” Analecta Bollandiana 91:11720.

— 1969. “'La servante de Dieu”: Poemenia d'après Pallade, la tradition copte et Jean Rufus.” Analecta Bollandiana 87:189-208.

Dietz, M. 2005. Wandering monks, virgins and pilgrims. Ascetic travel in the Mediterranean world, 300-800, University Park, PA: The Pennsylvania State University. 
o estranho percurso de Melânia-a-Antiga num Mediterrâneo globalizado

Drijvers, J. W. 1992. Helena Augusta: the mother of Constantine the Great and the legend of her finding of the True Cross. Leiden: Brill.

Durand, M.-G. 1976. "Evagre le Pontique et le 'Dialogue sur la vie de saint Jean Chrysostome’” Bulletin de Littérature Écclésiastique 3:191-206.

Furtado, R. 2013. "Quando os santos se zangam: Melânia-a-Antiga, cuius nomen nigredinis testatur perfidiae tenebras (Hier. ep. 133.3).” In Mulheres: Feminino, Plural, coord. Cristina Santos Pinheiro, Anne Martina Emonts, Maria da Glória Franco e Maria João Beja, 125-41. Funchal: Nova Delphi.

Hamblenne, P. 1980. “Une 'conjuration' sous Valentinien?” Byzantion 50:198225.

Hunt, E. D. 1982, Holy Land Pilgrimage in the Later Roman Empire, a.d. 312460. Oxford: Oxford University Press.

Leroux, J.-M. 1972. “Jean Chrysostome et la querelle origéniste.” In Epektasis: mélanges patristiques offerts au cardinal Jean Daniélou, ed. J. Fontaine e Ch. Kannengiesser, 335-41. Paris: Beauchesne.

Maraval, P. 1985. Lieux saints et pèlerinages d'Orient: Histoire et géographie des origines à la conquête Arabe. Paris: Les Editions du Cerf.

Marcos, M. 2004. “El origen de la peregrinación religiosa en el mundo cristiano: Jerusalén y Roma." In Monasterios y peregrinaciones en la España Medieval, ed. J. A. García de Cortázar, 11-31. Palencia: Fundación Santa María La Real. Centro de Estudios del Romanico.

Mariano, A. B. e A. A. Nascimento. 1998. Egéria. Viagem do Ocidente à Terra Santa. Lisboa: Colibri.

Matthews, J. 1989. The Roman Empire of Ammianus. London: Duckworth.

Moine, N. 1980. “Melaniana.” Recherches Augustiniennes 15:3-79.

Pietri, C. 1976. Roma Christiana. Recherches surl'église de Rome, son organisation, sa politique, son idéologie, de Militade à Sixte III (311-440). Roma: École Française de Rome.

Pohlsander, H. A. 1996. Helena: Empress and Saint. Chicago: Ares Publishers.

Rubenson, S. 2008. "Asceticism and Monasticism, I. Eastern." Constantine to c. 600. In Vol. 2 de The Cambridge History of Christianity, ed. Augustine Casiday e Frederick W. Norris, 637-68. Cambridge: Cambridge University Press.

Turner, V. e E. Turner. 1978. Image and pilgrimage in Christian culture: anthropological perspectives. New York: Columbia University Press.

Vincenti, U. 1991. “Praescriptio fori' e senatori nel tardo impero romano d'Occidente." Index 19:433-40. 
Webb, D. 1999. Pilgrims and pilgrimage in the Medieval West. London: I. B. Tauris.

Wilkinson, J. 1977. Jerusalem pilgrims before the crusades. Warminster: Aris \& Phillips.

Wilkinson, K. W. 2012. “The Elder Melania's Missing Decade.” Journal of Late Antiquity 5:166-84. 
